\title{
A FELÜLETELŐKÉSZÍTÉS HATÁSA A FELÜLETI RÉTEG MARADÓ FESZÜLTSÉGI ÁLLAPOTÁRA HIDEGALAKÍTÓ SZERSZÁMACÉLOKON
}

\author{
Fülöp Fruzsina \\ MSc hallgató, Miskolci Egyetem, Magyarország \\ 3515 Miskolc, Miskolc-Egyetemváros, email: fulop.fruzsina@uni-miskolc.hu \\ Marosné Berkes Mária \\ egyetemi tanár, Miskolci Egyetem, Magyarország \\ Anyagszerkezettani és Anyagtechnológiai Intézet \\ 3515 Miskolc, Miskolc-Egyetemváros, email: maria.maros@uni-miskolc.hu
}

\begin{abstract}
Absztrakt
A szerszámacélok kopásállóságának, élettartamának növelésére gyakran alkalmazunk keramikus bevonatokat, amelyek teljesítőképességét nemcsak a bevonat sajátosságai határozzák meg, hanem nagymértékben befolyásolják a felületi- és felületközeli réteg tulajdonságai, többek között maradó feszültségi állapota. Ebben a cikkben mono- és multiréteges szuperkemény DLC bevonatolásra szánt X153CrMoV12 erősen ötvözött hidegalakító szerszámacélok esetében azt vizsgáltuk, hogy a bevonatolás előtt végzett, két elterjedten használt felületelőkészítési eljárást - a polírozást és az üveggyöngyszórást - követően milyen feszültségállapot alakul ki a szerszámacél felületközeli rétegében, összehasonlítva azt a megelözö lépcsőben, azaz a köszörüléskor kialakult maradó feszültségi állapottal. Megállapítottuk, hogy az egyes megmunkálási eljárások rendkívül eltérő feszültségállapotot eredményezhetnek, a köszörülést követően döntően húzó, a polírozás után jellemzően kismértékü nyomó, az üveggyöngyszórás hatására pedig, a polírozáshoz képest egy nagyságrenddel nagyobb, nyomó maradó feszültségek alakulnak ki.

Szakirodalmi tájékozódás alapján megállapítottuk, hogy ezek a maradó feszültségek nagymértékben módosíthatók a megmunkálás körülményeinek, technológiai paramétereinek változtatásával, hangsúlyozva, hogy a maradó feszültségek mellett számos más befolyásoló tényezőt is figyelembe kell venni a keramikus bevonatok alatti szubsztrát felületminőségének kialakításakor.
\end{abstract}

Kulcsszavak: keramikus bevonat, felületelökészités, maradó feszültség, szerszámacélok

\begin{abstract}
In order to increase the wear resistance and service life of tool steels, we often use ceramic coatings. The performance of these coatings is determined not only by their properties, but also significantly by the characteristics of the surface- and near-surface layer, including their residual stress state. In this paper we investigated the residual stresses developing during grinding, polishing and glass bead blusting in the surface layer of an X153CrMoV12 high-alloy cold forming tool steel, that is intended to be coated by mono- and multilayer superhard DLC coatings.

It has been found that each surface treat ment process can result in extremely different stress states, with predominantly tensile stresses after grinding, typically low compressive stresses after polishing, and compressive residual stresses one order of magnitude higher than for polishing as a result of glass bead
\end{abstract}


blasting. Based on the literature, we found that these residual stresses can be greatly modified by changing the processing conditions and technological parameters, emphasizing that in addition to the residual stresses, several other influencing factors must be taken into account when designing the surface quality of the substrate under the ceramic coatings.

Keywords: ceramic coatings, surface preparation, residual stresses, tool steels

\section{Bevezetés}

A munkadarabok megmunkálása során a felületi és felületközeli rétegekben a feszültségi állapot megváltozik. A gyakorlatban elterjedten alkalmazott felületelőkészítési eljárások, mint például a köszörülés, a polírozás vagy a szemcseszórás, eltérő maradó feszültségi állapotot eredményeznek a felületi rétegben. Ez jelentősen befolyásolhatja a felület müködési tulajdonságait, mivel a maradó feszültségek a külső terhelésre szuperponálódva együttesen határozzák meg az anyag igénybevételét. Különösen fontos a maradó feszültségi állapot ismerete például a fáradásnak, kopásnak kitett szerkezetek esetében, de a felület előkészítése nyomán kialakuló maradó feszültségi állapot jelentősen befolyásolhatja a különféle bevonatrendszerek müködését, élettartamát is. Mechanikai igénybevételnek kitett alkalmazásokban általában a felületi rétegben ható nyomó maradó feszültségek a kedvezőek, míg a húzó feszültségek segíthetik a repedések kialakulását és terjedését [1]. Ebben a cikkben a X153CrMoV12 hidegalakító szerszámacél köszörült, polírozott és üveggyöngyszórással kezelt felületein és felületközeli rétegeiben kialakult maradó feszültségi állapotot elemeztük azzal a céllal, hogy a szerszámanyagok élettartamának növelése céljából alkalmazott kemény, illetve szuperkemény keramikus bevonatok felvitelét megelőző állapotot tanulmányozzuk.

\section{A maradó feszültségek sajátosságai}

\subsection{A maradó feszültség fogalma, típusai}

Maradó feszültség alatt azokat a mechanikai feszültségeket értjük, amelyek külső terhelés (erő, nyomaték) által nem terhelt szilárd testben egyensúlyban vannak. A maradó feszültségek azokból az anyagtechnológiai folyamatokból származnak, amelyek alakváltozást okoznak. Kialakulásukat a gyártási folyamatok közben fellépő inhomogén képlékeny alakváltozások, az inhomogén hőeloszlásból származó, vagy az eltérő hőtágulású anyagrészekben keletkező inhomogén hőtágulás, illetve olyan anyagszerkezeti változás okozza, amelynek során eltérő fajtérfogatú anyagrészek jönnek létre.

A mechanikai terheléssel járó folyamatok általában nyomó jellegü, az egyenlőtlen hőmérsékleteloszlást okozó eljárások inkább húzó jellegü maradó feszültség kialakulásához vezetnek a felületközeli rétegekben. A különféle fázisátalakulások és ezzel járó anyagszerkezet módosulások mind húzó-, mind nyomó maradó feszültségeket okozhatnak.

A maradó feszültségek tehát természetes velejárói a megmunkálási folyamatoknak, ezért nem lehet elkerülni a kialakulásukat. A maradó feszültségeknek három típusát különböztetjük meg $[1,2]$ :

- I. rendủ, vagy makroszkopikus maradó feszültségek (milliméterben mérhető vagy annál nagyobb távolságokra ható feszültségek);

- II. rendủ vagy mikroszkopikus (mikrométerben mérhető, jellemzően a szemcseméretek nagyságrendjébe eső távolságokra ható feszültségek); 
- III. rendü, vagy szubmikroszkopikus maradó feszültségek (nanométerben mérhető, atomi szintü távolságokra ható feszültségek).

\subsection{A maradó feszültségek hatása, jellege, nagyságrendje}

Számos fémmegmunkáló eljárás húzó jellegü maradófeszültségeket okoz és a külső terhelésre szuperponálódva káros a szerkezetekre nézve. Ha a munkadarab ismétlődő terhelésnek van kitéve, a szerkezet felületi rétegében jelenlévő húzó maradó feszültségek idő előtti repedéskeletkezéshez, majd azok terjedéséhez vezethetnek.

A hagyományos nagyoló forgácsoló megmunkálok, amelyek jelentős képlékeny alakváltozást okoznak a felületközeli rétegekben - esztergálás, marás, köszörülés - általában jelentős nyomó maradó feszültségeket hoznak létre [3], de a technológia paraméterektől függően a feszültségek eloszlása a felületen és a felületközeli rétegben $(10-100 \mu \mathrm{m}$ mélységben) rendkívül eltérô jelleget mutathat $[4,5]$. A nagyobb hőbevitellel járó megmunkálások esetén, amelyek során fázisátalakulások is bekövetkezhetnek a húzó maradó feszültségek jelentősen megnövekedhetnek.

Különféle forgácsoló megmunkálások után a felületközeli rétegekben kialakult maradó feszültségeloszlására mutat példát a 1 . ábra.

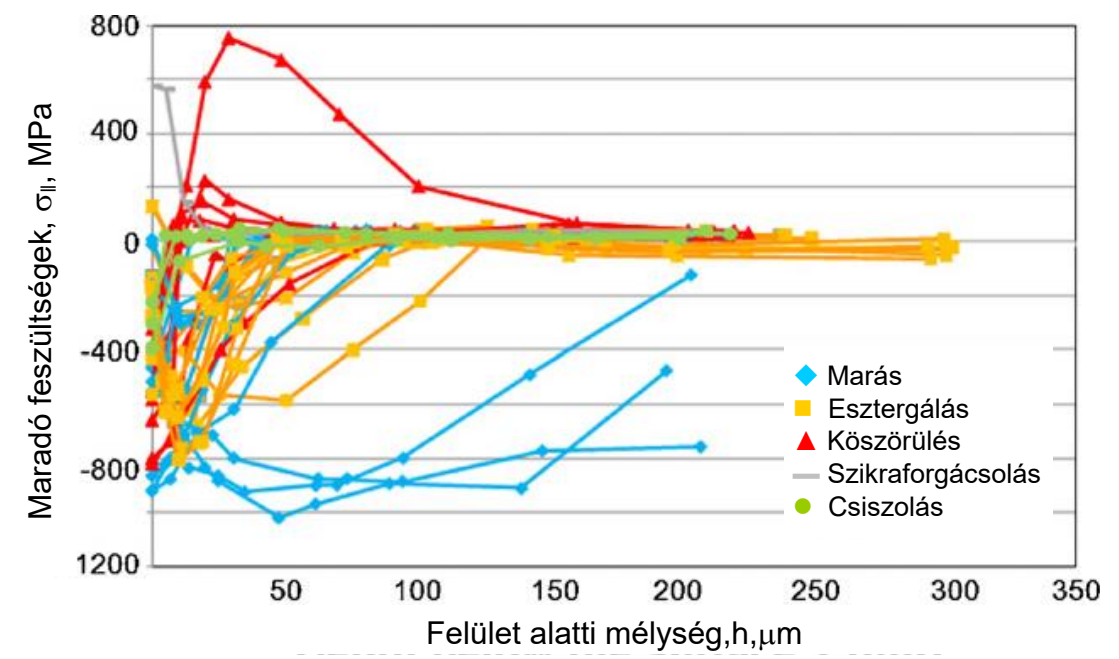

1. ábra. Röntgendiffrakciós módszerrel különféle megmunkálások után meghatározott maradó feszültségi profilok (az azonos szinü profilok változó paraméterü, azonos megmunkálásokhoz tartoznak) [3]

Az egyes megmunkálásokat tekintve esztergáláskor közvetlenül a felületen kismértékủ húzó, a felületközeli rétegben pedig jellemzően nyomó maradó feszültségek jönnek létre.

Ezzel szemben a köszörülés általában közvetlenül a felület alatt nyomó, majd kissé mélyebben, a felületközeli rétegekben néhány $10 \mu \mathrm{m}$-es mélységig döntően húzó feszültséget hoz létre (2/a. ábra) [6], bár jellege a köszörülés paramétereitől függően igen jelentősen változhat (1. ábra). Számos kutatás számol be arról, hogy a köszörülés technológiai paraméterein keresztül (fogásmélység, sebesség, előtolás, abrazív szemcse anyaga, hütési mód és folyadék típusa) nagymértékben befolyásolhatjuk a kialakuló maradó feszültségek nagyságát, sőt jellegét (húzó, nyomó) is [5, 7, 8]. 
Polírozáskor a kisebb mértékủ képlékeny alakváltozásnak megfelelően kisebb mértékű nyomó maradó feszültségek jönnek létre a felület alatt például a finomesztergáláshoz képest (2/b. ábra).

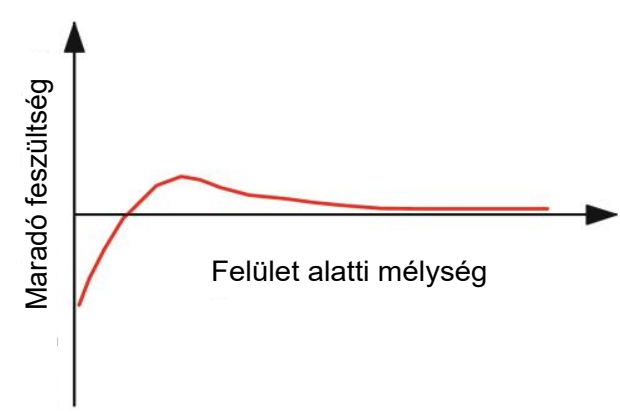

a)
Felület alatti mélység, $h, \mu \mathrm{m}$

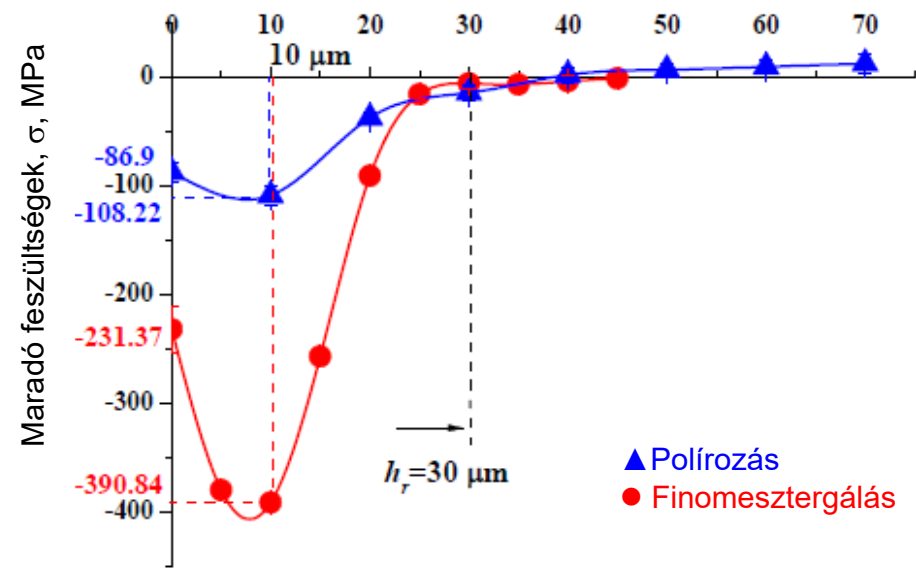

b)

2. ábra. Maradó feszültségek jellegzetes eloszlása a felület alatti rétegben

(a) köszörülés után 8; (b) polírozás és finomesztergálás után [9]

A kovácsolás kisebb mértékű [10], az ütőtestes megmunkálások a fémek felületi rétegében jelentős nagyságú nyomó maradó feszültséget alakíthatnak ki (3. ábra), amelyek növelik a munkadarab kifáradási határát és élettartamát $[11,12]$.

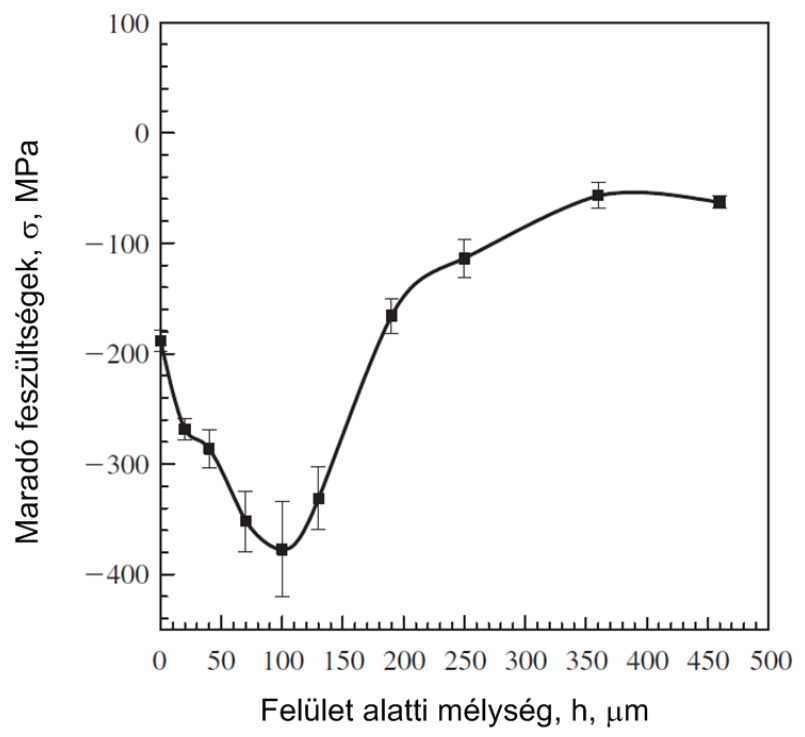

3. ábra. Si-Mn tartalmú rugóacélban sörétezés után kialakult maradó feszültségi állapot [13]. 
Az ütőtestes felületszilárdítás mértékétől (idejétől) függően ez a maradó feszültségi állapot jelentős eltéréseket mutathat.

A 4. ábrán köszörült, valamint különböző mértékü sörétezési müvelet után, AISI 4340 acéllemezben kialakult maradó feszültségek eloszlása látható. A köszörült állapothoz képest a felület mindössze 3\%ára kiterjedő sörétezése után a felület közelében kialakult maximális nyomó maradó feszültség értéke kétszeresére nőtt. Amint az az ábrából látható, a sörétezés idejének növelésével ennek nagysága kevéssé változott, ugyanakkor a maximális nyomó maradó feszültségü zóna mélysége jelentősen - néhány 10 mikrométerről 100 mikrométerre növekedett.

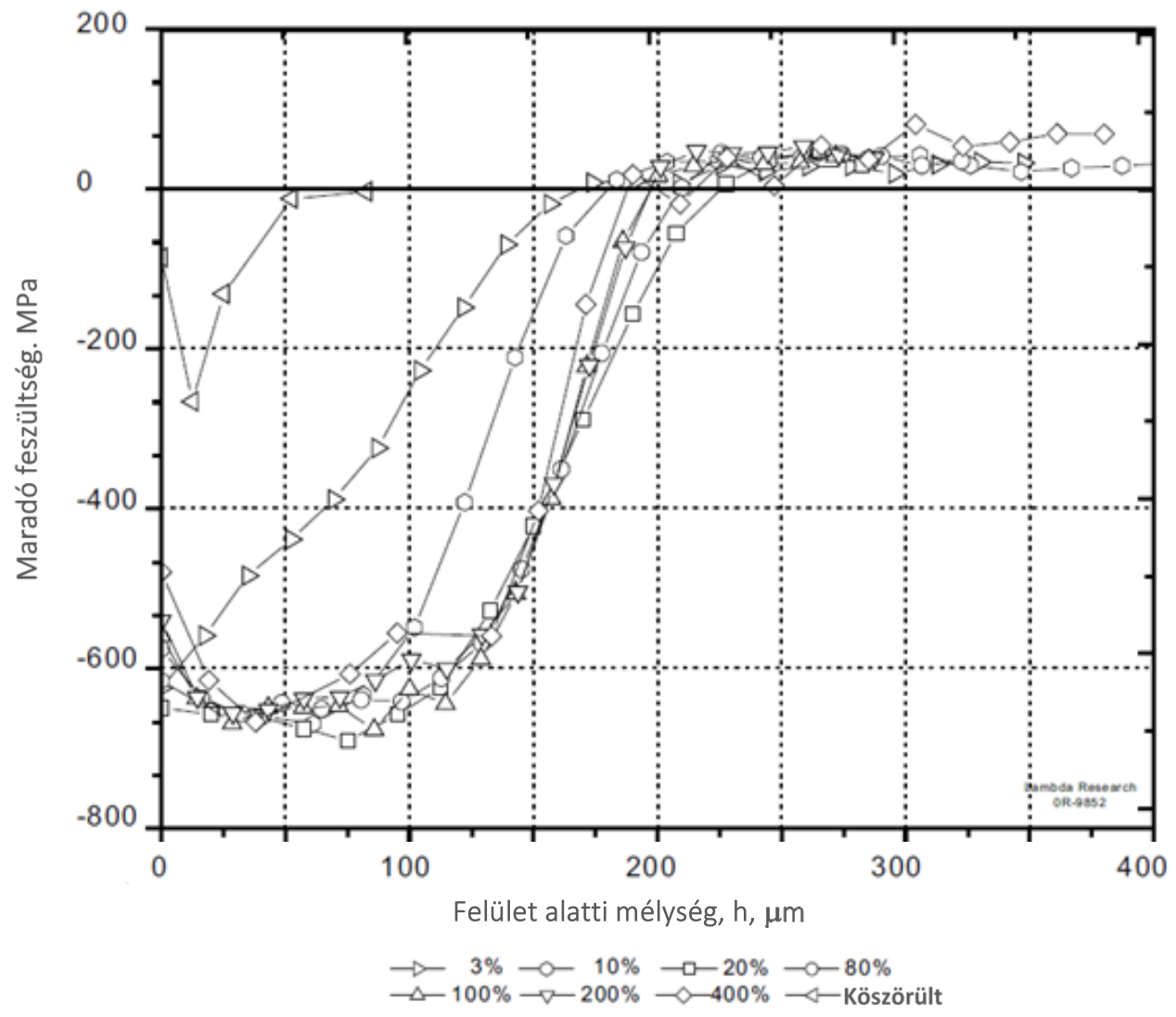

4. ábra. Különbözö mértékü sörétezés után AISI 4340 acéllemezben kialakult maradó feszültségek eloszlása. A \%-ban kifejezett viszonyszám a sörétezés idejét fejezi ki a teljes, azaz a felületet 100\%-ban lefedö sörétezés idöszükségletéhez képest [14]

A megmunkálások elött, közben, vagy után elvégzett hőkezelési mủveletek ugyancsak jelentős maradó feszültségek kialakulásával járhatnak. Az edzés és megeresztés, amelyek a kiválásosan keményített ötvözetek hökezelésének részfolyamatai, ugyancsak számottevő maradó feszültséget generáló eljárások. Edzett, majd azt követően azonos hőmérsékleten, különböző időtartam alatt megeresztett acélban kialakult maradó feszültségek felület alatti eloszlását illusztrálja a 5/a. ábra. 
A kedvezőtlen, a felületi rétegben minden esetben húzó jellegű maradó feszültségeket az edzést és megeresztést követő ütőtestes megmunkálással viszont igen jelentős mértékben módosíthatjuk (5/b. ábra), jelentős mértékủ nyomófeszültséget eredményezve a felületi rétegben.

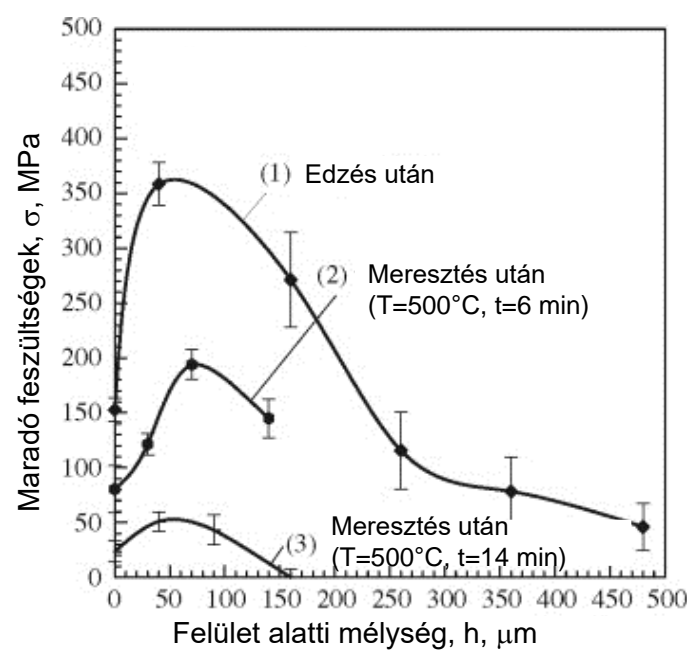

a)

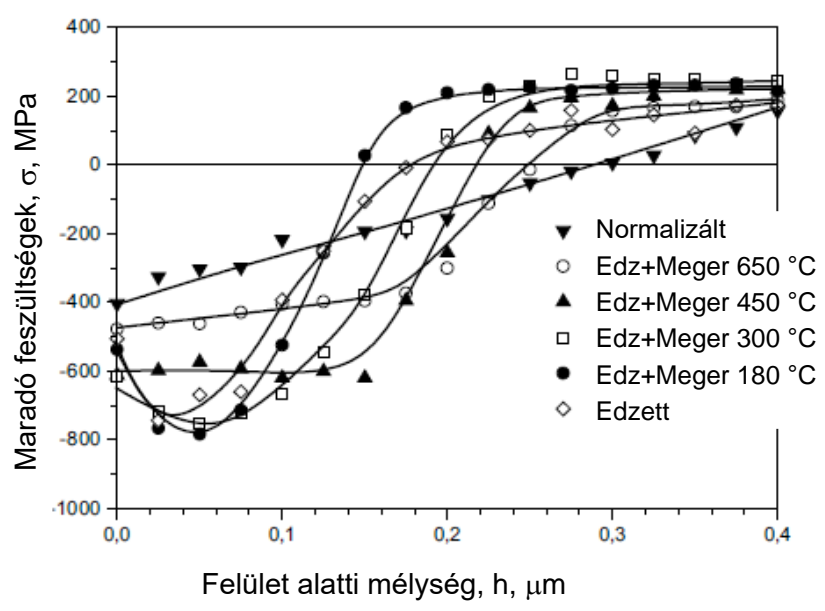

b)

5. ábra. Különbözö hö- és felületkezelésü ötvözetekben kialakult maradó feszültségek

(a) Si-Mn ötvözésü acélban edzés, illetve azonos hömérsékletü, különbözö idötartamú megeresztés után [13], (b) Különféle hökezelésü 42CrMo4 acélban azonos paraméterekkel végzett sörétezés után [11]

\subsection{A maradó feszültségek mérése}

A maradó feszültségek mérése csak a gyártási folyamat után lehetséges különböző mechanikai, vagy fizikai módszerekkel.

A mechanikai mérési eljárások csoportjába tartoznak a rétegeltávolítási feszültségrelaxációs módszerek, például a vágás, a lyukfúrás, illetve a magfúrás.

A fizikai módszerek közül a legfontosabbak az általunk is alkalmazott röntgendiffrakciós, neutron diffrakciós, továbbá akusztikus, illetve mágneses elven alapuló eljárások.

A röntgendiffrakciós vizsgálat egyik legfontosabb előnye, hogy az anyag roncsolása nélkül végezhető, így a munkadarab felülete sérülésmentes marad. A módszerrel a jelenlévő, rugalmas alakváltozást okozó maradó feszültségröl kapunk információt.

\section{Kísérleti munka}

Az itt bemutatott kutatómunka célja keramikus - mono- és multiréteges DLC - bevonatolásra szánt hidegalakító szerszámacél különböző felületelőkészítésü - köszörült, köszörült+polírozott, illetve köszörült+polírozott+üveggyöngyszórt-minták felületeinek és felületközeli rétegeiben kialakult maradó feszültségek vizsgálata elsősorban azzal a céllal, hogy az alkalmazott felületelőkészítő eljárások 
után kialakult maradó feszültségi állapotok közül melyik lehet legkedvezőbb a kopásálló bevonatok müködése szempontjából.

\subsection{Vizsgált alapanyag}

A vizsgált próbatestek alapanyaga X153CrMoV12 erősen ötvözött hidegalakító szerszámacél, amelynek EN-számjele 1.2379 (Böhler acélminőség). Az anyag vegyi összetételét az 1. táblázat [15] tartalmazza.

1. táblázat. X153CrMoV12 hidegalakitó szerszámacél átlagos vegyi összetétele, tömeg\%-ban

\begin{tabular}{|c|c|c|c|c|c|c|c|c|c|}
\hline $\mathrm{C}$ & $\mathrm{Si}$ & $\mathrm{Mn}$ & $\mathrm{Cr}$ & $\mathrm{Mo}$ & $\mathrm{Ni}$ & $\mathrm{V}$ & $\mathrm{W}$ & Co & Egyéb \\
\hline 1,55 & 0,30 & 0,30 & 11,30 & 0,75 & - & 0,75 & - & - & - \\
\hline
\end{tabular}

A vizsgált acélminőséget szerszámanyagként általában kiválásosan keményített állapotban használják, ezért az alapanyagon ilyen jellegü térfogati hőkezelés történt, a következő technológiai paraméterekkel: edzési (ausztenitesítési) hőmérséklet: $1070{ }^{\circ} \mathrm{C}$-on, majd hütés levegőn. Az első megeresztés hőmérséklete $520^{\circ} \mathrm{C}$ (a szekunder keményedés maximumához tartozó hőmérséklet) volt, a második megeresztés hőmérséklete $550{ }^{\circ} \mathrm{C}$ volt, ami jellemzően a darab maximális üzemi hőmérséklete. Mindkét megeresztés esetén két óra volt a hőntartási idő, amelyet levegőn történő hütés követett.

Ennek a hökezelésnek a hatására az alapanyag keménysége átlagosan HV10=650 értékü lett.

\subsection{A vizsgálati minták felületelőkészítése}

A próbatestek 29,97 mm átmérőjü, lágyított állapotú rúdból készültek, amelyekből gépi forgácsolással $6,3 \mathrm{~mm}$ magas pogácsákat daraboltak. A mintaelőkészítés során szükséges mintabefogás elősegítésére a pogácsák két oldalát lelapolták, majd az így elkészült darabokon az előző pontban ismertetett hőkezelési paraméterekkel kiválásos keményítést végeztek.

A mintákat ezt követően háromféle felületelőkészítési metódus szerint készítettük elő. Egy részüket síkköszörü segítségével a próbatestek mindkét homlokfelületén megköszörültük (köszörült minták).

Egy másik részüknél a köszörülést követően a felületüket políroztuk (köszörült és polírozott minták). A polírozási múveletet Struers LaboPol-21 kéttárcsás csiszoló- és polírozógépen végeztük. A csiszoláshoz SiC csiszolópapírt és $\phi 3 \mu \mathrm{m}$ átmérőjü gyémántszemcsét tartalmazó pasztát alkalmaztunk. A polírozás DP-Lubricant Green kenőfolyadékkal történt.

A minták harmadik csoportjában a felületelőkészités három lépésből állt, vagyis a köszörülés és polírozás után a próbatesteket üveggyöngyszórással kezeltük (köszörült, polírozott és üveggyöngyszórt minták). Ezt az eljárást gyakran használják az iparban a felületek tisztítására, előkészítésére. Jellemzően a bonyolult geometriájú alkatrészek esetén előnyösen alkalmazható, gyors és hatékony technológia. Az általunk vizsgált próbatestek esetén az üveggyöngyszórás 40-70 $\mu \mathrm{m}$ szemcseméretü üveggyönggyel történt, amelynek összetétele $72-75 \% \mathrm{SiO}_{2}$ és $14 \% \mathrm{Na}_{2} \mathrm{O}_{3}$ volt. 


\subsection{Röntgendiffrakciós vizsgálat}

Roncsolásmentes röntgendiffrakciós eljárással a felületen lévő rugalmas alakváltozást okozó maradó feszültségekről kaphatunk információt. A vizsgálatok az MSZ EN 15305:2009 szabvány [16] szerint lettek elvégezve Stresstech Xstress 3000 G3R röntgendiffraktométerrel, amely vonaldetektorokat használ a vizsgált $\Theta$ szögtartományban.

A mérés során az adatgyüjtési idő $4 \mathrm{~s}$ volt, míg a döntési pozíció $3 / 3$. Az alkalmazott mérési paraméterek az alábbiak voltak: csőfeszültség: $30 \mathrm{kV}$, csőáram: $9 \mathrm{~mA}$, röntgencső anyaga: $\mathrm{Cr}$, mért reflexió: ferrit $\{221\}$.

A különböző felületelőkészítésủ mintákon egyrészt meghatároztuk a felületen mérhető húzó/nyomó, illetve nyírófeszültségek értékét, másrészt vizsgáltuk a mélység irányú maradó feszültség-eloszlást is a felület alatti $\mathrm{kb} .50 \mu \mathrm{m}$ vastagságú rétegben.

\subsection{Vizsgálati eredmények}

A vizsgálatokat a különböző módon előkészített minták mindkét oldalán elvégeztük, oldalanként 1-6 mérési pontban mérve a normálfeszültségek $(\sigma)$, illetve nyírófeszültségek $(\tau)$ nagyságát. A mért értékek átlagát számszerủen a 2. táblázat foglalja össze, míg az egyes felületelőkészítő eljárások után átlagosan mért maradó feszültségek értékét a felületen az 6. ábra illusztrálja.

2. táblázat. A minták felületén mért maradó feszültségek

\begin{tabular}{|c|c|c|c|c|c|c|}
\hline Minta felületelökészítése & Oldal & $\begin{array}{l}\text { Mérések } \\
\text { száma }\end{array}$ & $\sigma, \mathrm{MPa}$ & $\begin{array}{c}\text { szórás, } \pm \\
\text { MPa }\end{array}$ & $\tau, \mathrm{MPa}$ & $\begin{array}{l}\text { szórás, } \\
\pm, \mathrm{MPa}\end{array}$ \\
\hline \multirow{3}{*}{ Köszörült } & A & 5 & 35,08 & 6,9 & 32,42 & 1,5 \\
\hline & $\mathrm{B}$ & 3 & $-159,50$ & 5,87 & $-19,13$ & 3,9 \\
\hline & $A+B$ átlag & 8 & $-62,21$ & - & 6,65 & - \\
\hline \multirow{3}{*}{$\begin{array}{l}\text { Köszörültt + } \\
\text { Polírozott }\end{array}$} & A & 3 & $-75,30$ & 19 & $-0,47$ & 4,2 \\
\hline & $\mathrm{B}$ & 3 & $-201,73$ & 24,6 & $-3,33$ & 5,5 \\
\hline & $A+B$ átlag & 6 & $-138,52$ & - & $-1,90$ & - \\
\hline \multirow{3}{*}{$\begin{array}{l}\text { Köszörült + } \\
\text { Polírozott+ } \\
\text { Üveggyöngyszórt }\end{array}$} & $\mathrm{A}$ & 6 & $-942,75$ & 13,3 & $-15,77$ & 3 \\
\hline & $\mathrm{B}$ & 1 & $-936,1$ & 15,8 & $-1,6$ & 3,5 \\
\hline & $A+B$ átlag & 7 & $-939,43$ & - & $-8,69$ & - \\
\hline
\end{tabular}

Az egyes felületelőkészítő eljárások után kialakult maradó feszültségeket összehasonlítva az alábbi megállapítások tehetők:

- A normál- és a nyírófeszültségek átlagos értékei azonos tendenciát mutatnak (2. táblázat), ezért a további elemzések során csak a normálfeszültségekre vonatkozó mérési eredményeket részletezzük.

- A köszörülés után a felületi maradó feszültségek az egymással szemközti két oldalon jelentősen eltértek. Míg az egyik oldalon húzó (35 MPa), a másik oldalon nyomó (-159,5 MPa) maradó 
feszültségek alakultak ki. Ennek hátterében az állhat, hogy a síkköszörülés - amely a minták két szemközti homlokfelületén egymást követő lépésekben történt - eltérő módon módosította a kiválásosan keményített minták maradó feszültségi állapotát, amelyek az egyik oldalon bekövetkezett anyagleválasztást követően átrendeződtek. A köszörülést megelőző, a kiválásos keményítés után kialakult maradó feszültségi állapotra vonatkozóan mérési eredmények nem állnak rendelkezésünkre, de a mért értékek nyilvánvalóan a hökezelés és köszörülés hatására kialakult maradó feszültségek szuperponálódásának eredményét tükrözik.

- A köszörülést követő polírozással kismértékủ nyomó maradó feszültséget vittünk be a felületi rétegbe, amelyek átlagosan -(50-100) MPa-lal csökkentették a köszörüléskor kialakult maradó feszültségek értékét. Ez összességében az egyik oldalon -75,3 MPa, míg a másik oldalon -201,7 MPa értékü nyomó maradó feszültséget eredményezett.

- Az így elökészített (köszörült + polírozott) felületeken végrehajtott üveggyöngy-szórás a nyomó maradó feszültségek értékét többszörösére növelte, amely átlagosan mintegy -940 MPa értékü volt.

Itt kell megjegyezni, hogy az üveggyöngyszórást az ipari gyakorlatban természetesen nem elözi meg polírozási müvelet, csak köszörülés. A polírozási müvelet itt azért jelenik meg az üveggyöngy-szórás elött, mivel csak ilyen minta állt rendelkezésünkre a kísérlet adott szakaszában. Ugyanakkor a mérési eredmények birtokában egyértelmüen elmondható, hogy az üveggyöngy-szórás után kialakult maradó feszültségi állapot jellegét (húzó/nyomó) és nagyságát $(\sigma<-900 \mathrm{MPa})$, a köztes polírozási müvelet érdemben nem befolyásolta.

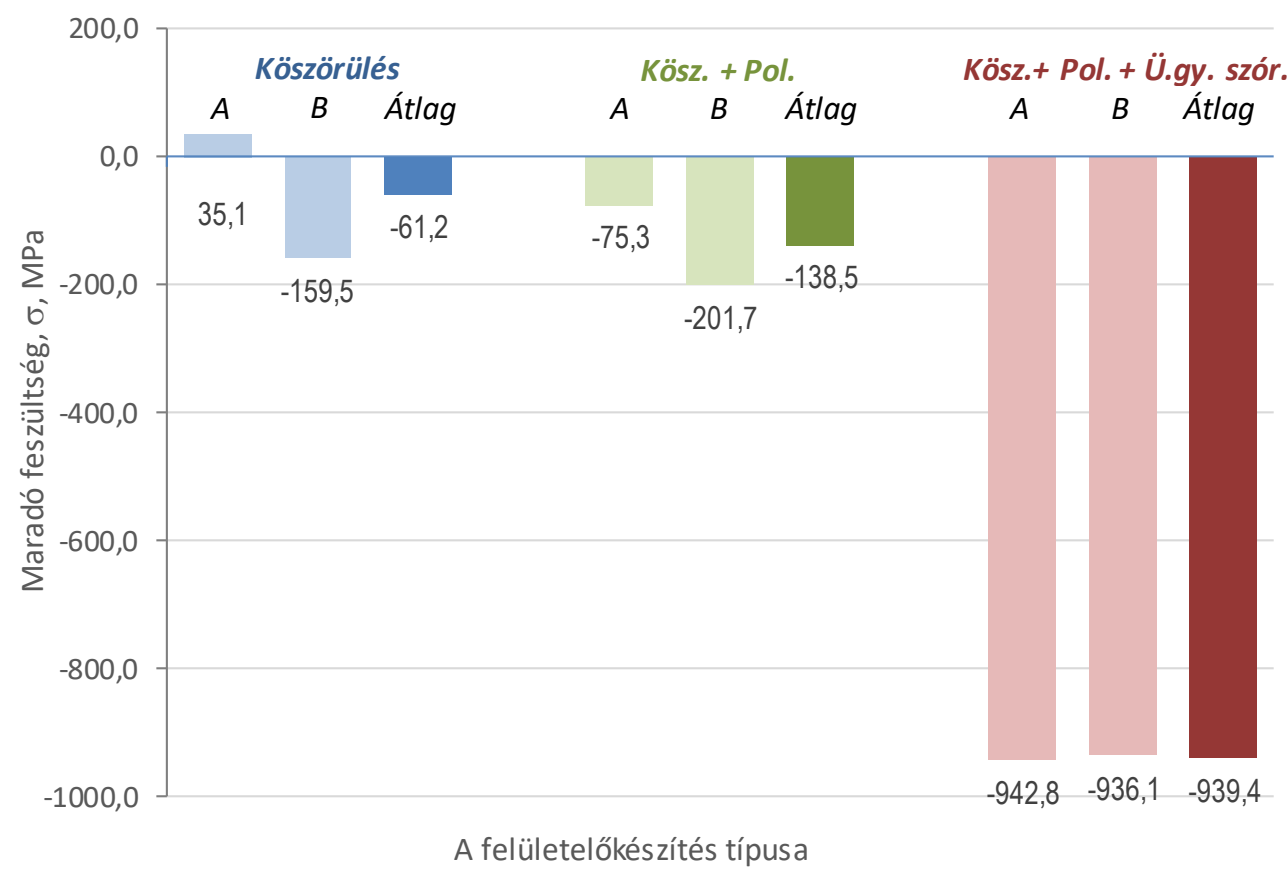

6. ábra. A felületi maradó feszültségek összehasonlitása a különbözö felületelökészitésü mintákon 
A vizsgált felületelőkészítési eljárások a felület alatt különböző mélységekben is eltérő nagyságú maradó feszültségeket eredményeztek. A maradó feszültségek mélységirányú eloszlása a 7. ábrán látható.

- Megállapítható, hogy a kiválásosan keményített szerszámacélon elvégzett köszörülési eljárás után döntően húzófeszültség maradt az anyagban. A feszültség eloszlását részletesebben is megvizsgálva a 7. ábrán látható, hogy a köszörülést követően a felületi rétegekben, kb. 5-10 $\mu \mathrm{m}$ mélységig alakult ki negatív, azaz nyomó maradó feszültség, a mélyebb rétegekben ezzel szemben húzófeszültség jött létre. Fontos ismételten megemlíteni, hogy a tapasztalt feszültségeloszlás két egymást követő technológia együttes eredménye, vagyis az 7. ábrán a köszörült felületekhez tartozó görbék a megelőző kiválásos keményítés és az azt követő köszörülés összegzett hatását jelenítik meg, a minta két oldalán aszimmetrikus feszültségeloszlással. A köszörüléshez tartozó görbék kezdeti szakaszának jellege (inflexiós átmenet) arra utal, hogy a kiválásos keményítés után kismértékü húzófeszültségek uralkodtak a felületen.

- A köszörülést követő polírozási művelet után a felületközeli vékony rétegben, kb. 2-3 $\mu \mathrm{m}$ mélységig kismértékủ nyomófeszültség figyelhető meg, amelyet nagyobb mélységben kismértékű húzófeszültség követ. Ez a két maradó feszültségi érték 10-30 $\mu \mathrm{m}$ mélységben kiegyenlítődik és gyakorlatilag zérussá válik. Fontos megjegyezni, hogy a polírozás után tapasztalható húzófeszültségek a megelöző köszörülési müveletnek tulajdoníthatók, amelyek a polírozáskor létrejött nyomófeszültségek hatására átrendeződtek. A polírozás során érintett felületi réteg vastagsága kisebb, mint a köszörüléssel megmunkált rétegé.

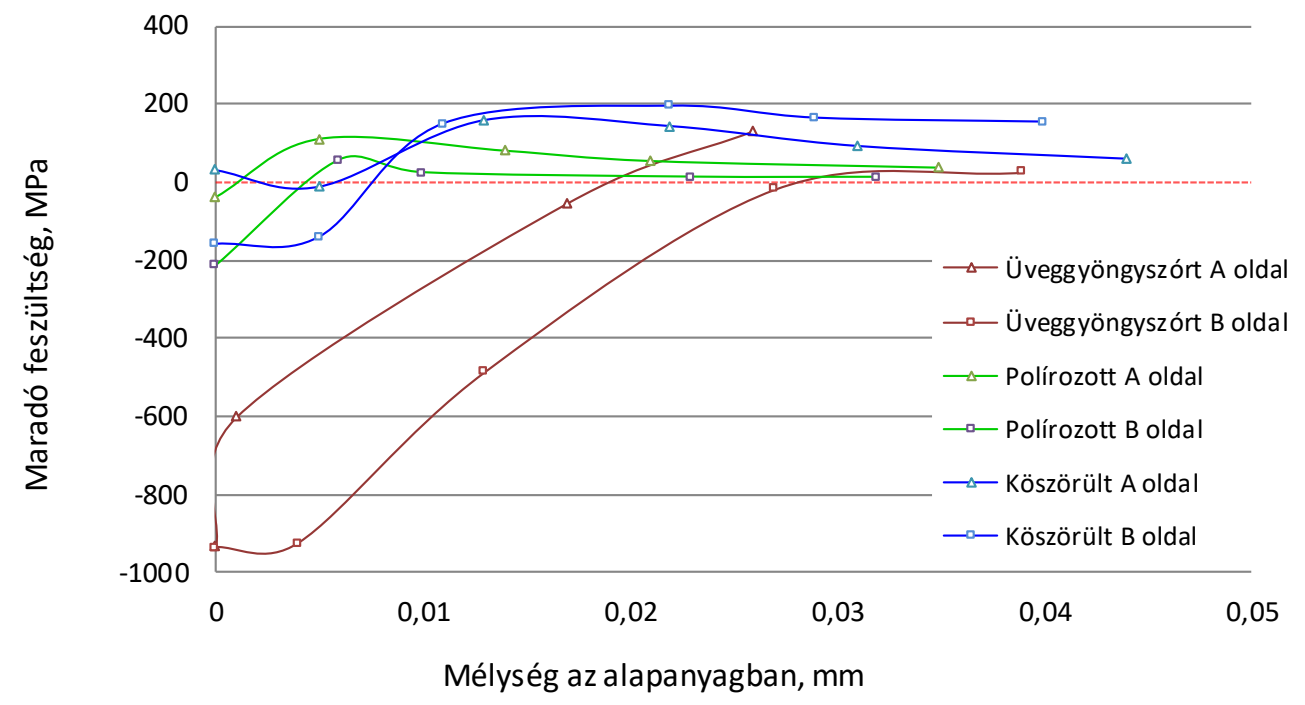

7. ábra. A maradó feszültségek mélységirányú eloszlása a különbözö felületelökészitésü munkadarabok esetén

Amennyiben a köszörült és polírozott mintákon üveggyöngyszórást is végzünk a felületközeli rétegekben nagy nyomófeszültség alakul ki. Ez a hatás kb. 20-30 $\mu \mathrm{m}$ mélységig figyelhető meg. Ez összhangban van azzal az általános tapasztalattal, amely szerint a nagyenergiájú ütötestek becsapódásakor a fémes anyagban bekövetkező jelentős képlékeny alakváltozás hatására viszonylag 
nagy nyomó maradó feszültségek jönnek létre, és ez a hatás a köszörülés által érintett rétegvastagsághoz képest jóval nagyobb mélységekig terjed a felület alatt.

A kapott mérési eredményeket összehasonlítva a szakirodalomban közölt eredményekkel megállapítható, hogy azokkal mind a feszültségek jellegét és nagyságát, mind a különféle megmunkálások után kialakult maradó feszültségek mélységi kiterjedését (hatótávolságát) illetően összhangban vannak [7-11; 13-14].

\section{4. Összefoglalás}

Kiválásosan keményített, X153CrMoV12 hidegalakító szerszámacél felületi rétegében a különböző felületelőkészítési müveletek - köszörülés, polírozás és üveggyöngyszórás - után a felületi rétegben kialakult maradó feszültségek eloszlását vizsgáltuk azzal a céllal, hogy az adott szerszámanyag kopásállóságának növelését célzó bevonatolási eljárásra gyakorolt lehetséges hatásukat megítéljük.

A kapott vizsgálati eredmények alapján elmondható, hogy a különbözö felületelökészitési eljárások eltérő maradó feszültséget eredményeztek az alapanyag felületközeli rétegében.

A bevonatolás elött alkalmazott polírozás kicsiny érdesség biztosítása mellett a leghomogénebb feszültségállapot - kismértékủ nyomó feszültség a felület közvetlen közelében, majd kismértékủ húzó, nagyobb mélységekben pedig közel zérus értékủ maradó feszültségek - kialakulását eredményezi. Emellett a vizsgált módszerek közül a legfinomabb felületminőséget biztosítja, amely a bevonatok tapadóképessége, integritása tekintetében előnyösebb [17].

$\mathrm{Az}$ üveggyöngyszórás hatására a felületközeli rétegben kialakuló, nagyságrenddel nagyobb nyomófeszültségek a mechanikai igénybevétel szempontjából nyilvánvalóan kedvezőbbek lehetnek, amennyiben ezek hatása bevonatkészítés után is érzékelhető mértékü. Ugyanakkor a megmunkálás okozta durva felület - nagy átlagos érdesség és hullámosság - a rideg, keramikus bevonatok kialakítása szempontjából olyan problémát vet fel, mint például az egyenlőtlen rétegvastagság, és ennek következményei a kopással és karcolással szembeni ellenállásra gyakorolt hatás révén $[17,18]$.

Kísérleteinkkel igazoltuk a szakirodalomban publikált azon tapasztalatokat, amelyek szerint a fémes alapanyagban a bevonatolást közvetlenül megelőzően kialakuló maradó feszültsági állapotot mindazon müveletek befolyásolják, amelyeket a munkadarabon megelőzőleg elvégeztek. A kialakuló maradó feszültségi állapot ezeknek a müveleteknek az összegzett hatását, az egyes müveletek által indukált maradó feszültségek szuperpozíciójaként kialakult állapotot tükrözi. Jellegüktől és nagyságuktól függően a termékek müködési tulajdonságait, élettartamát igen jelentősen módosíthatják, ismeretük és tudatos kézben tartásuk - amelyre a technológia paramétereken és megmunkálási körülményeken keresztül széles tartományban van lehetőségünk - egyre nagyobb jelentőséggel bír.

A cikkben bemutatott vizsgálati eredmények összhangban vannak a szakirodalomban található eredményekkel mind a feszültségek jellegét és nagyságát, mind a különféle megmunkálások után kialakult maradó feszültségek mélységi kiterjedését (hatótávolságát) illetően.

A maradó feszültségek figyelembevétele a későbbi felületmódosító eljárások - pl. bevonatolás szempontjából azért fontos, mert jelentősen befolyásolhatják a bevonat mechanikai viselkedését, tapadószilárdságát, ezzel a bevonatolás révén megcélzott tulajdonságjavulás (kopásállóság, kifáradással szembeni ellenállás stb.) élettartam növekedés mértékét. Ennek igazolása további kísérleteket igényel, amelyek közül a kopással és karcolással szembeni ellenállás vizsgálatára vonatkozó első eredmények más munkákban bemutatásra kerültek [17]. 


\section{Köszönetnyilvánítás}

A kutató munka részben az Európai Unió és a magyar állam támogatásával, az Európai Regionális Fejlesztési Alap társfinanszírozásával, a GINOP-2.3.4-15-2016-00004 projekt keretében valósult meg, a felsőoktatás és az ipar együttmüködésének elősegítése céljából, részben az NTP-SZKOLL-18-0040 azonosítószámú „Fókusz'19 - Középpontban a közösség” projekt keretében valósult meg az Emberi Erőforrások Minisztériuma és az Emberi Erőforrás Támogatáskezelő támogatásával.

A szerzők köszönetet mondanak a Miskolci Egyetem, Anyagszerkezettani és Anyagtechnológiai Intézete munkatársainak a próbatestek kimunkálásában és felületelőkészítésében, továbbá a Fémtani Képlékenyalakítási és Nanotechnológiai Intézete munkatársainak, Prof. Dr. Mertinger Valériának és Angel Dávidnak a maradó feszültségek röntgendiffrakciós meghatározásában nyújtott értékes segítségért, valamint Széll Attilának a (TS Magyarország Kft.) a kísérleti munka keretében tanulmányozott korszerü kopásálló bevonatok biztosításáért.

\section{Hivatkozások}

[1] Totten, G. E., Scott MacKenzie, D.: Handbook of Aluminium, Marcel Dekker, Inc., 2003

[2] Heinzel C.: Residual Stress (Abrasive Processes). In: The International Academy for Produ, Laperrière L., Reinhart G. (eds) CIRP Encyclopedia of Production Engineering. Springer, Berlin, Heidelberg, 2016, https://doi.org/10.1007/978-3-642-35950-7

[3] Jawahir, I. S., Brinksmeier, E., M'Saoubi, R., Aspinwall, D. K., Outeiro, J. C., Meyer, D., ... Jayal, A. D. Surface integrity in material removal processes: Recent advances. CIRP Annals, 60(2), 2011, p.603-626. https://doi.org/10.1016/j.cirp.2011.05.002

[4] Arrazola, P. J., Kortabarria, A., Madariaga, A., Esnaola, J. A., Fernandez, E., Cappellini, C., ... Özel, T. (2014). On the machining induced residual stresses in IN718 nickel-based alloy: Experiments and predictions with finite element simulation. Simulation Modelling Practice and Theory, 41, 87-103. https://doi.org/10.1016/j.simpat.2013.11.009

[5] Mamalis, A. G., Kundrak, J., \& Gyani, K. (2002). On the Dry Machining of Steel Surfaces Using Superhard Tools . The International Journal of Advanced Manufacturing Technology, 19 (3), $157-162$. https://doi.org/10.1007/s001700200009

[6] Dudás, I.: Gépgyártástechnológia I. Jegyzet, Miskolci Egyetemi Kiadó, 2000

[7] Zhang, J., Wang, G. C., Pei, H.C.: Effects of grinding parameters on residual stress of 42CrMo steel surface layer in Grind-hardening, in: International Symposium on Mechanical Engineering and Material Science (ISMEMS 2017), Series: Advances in Engineering Research, ISBN 97894-6252-450-7, Available Online November 2017. https://doi.org/10.2991/ismems-17.2018.10

[8] Ding, W., Zhang, L., Li, Z., Zhu, Y., Su, H., \& Xu, J. (2016). Review on grinding-induced residual stresses in metallic materials. The International Journal of Advanced Manufacturing Technology, 88(9-12), 2939-2968. https://doi.org/10.1007/s00170-016-8998-1

[9] Wu, D., Zhang, D., Yao, C.: Effect of Turning and Surface Polishing Treatments on Surface Integrity and Fatigue Performance of Nickel-Based Alloy GH4169. Metals, 8(7), 2018, p.549. https://doi.org/10.3390/met8070549 
[10] Angel, D.: Maradó feszültség változásának vizsgálata autóipari alkatrész gyártása során, Szakdolgozat, Miskolci Egyetem, 2015, pp.1-109.

[11] Schulze, V.: Characteristics of Surface Layers Produced by Shot Peening. in: Shot Peening, Ed.: Wagner, L., 2003 Wiley-VCH Verlag GmbH \& Co. KGaA, ISBN: 3-527-30537-8ISBN, 2006, pp.143-160. https://doi.org/10.1002/3527606580.ch20

[12] Cseh, D.: Maradó feszültség relaxációja fárasztó igénybevétel közben, PhD értekezés, 2018, Miskolc, pp.1-172.

[13] Todinov, M. T.: Generic solutions for reducing the likelihood of overstress and wearout failures, in: Risk-Based Reliability Analysis and Generic Principles for Risk Reduction, Elsevier Science ISBN 978-0-08-044728-5, 2007. pp.239-263. https://doi.org/10.1016/B978-0080447285/50001-9

[14] Prevey, P. S., \& Cammett, J. T.: The Effect of Shot Peening Coverage on Residual Stress, Cold Work and Fatigue in a Ni-Cr-Mo Low Alloy Steel. Shot Peening, 2006, pp.295304. doi:10.1002/3527606580.ch37

[15] K110 anyagadatlap, Forrás: Böhler, Letöltés ideje: 2017. 10. 25. http://www.bohleredelstahl.com/en/K110.php

[16] MSZ EN 15305:2009, Roncsolásmentes vizsgálatok. A maradó feszültség elemzésének röntgensugaras diffrakciós vizsgálati módszere; Non-destructive Testing. Test Method for Residual Stress analysis by X-ray Diffraction

[17] Fülöp, F.: Hidegalakító szerszámacél különböző DLC bevonatrendszereinek tribológiai jellemzése, Szakdolgozat, Miskolci Egyetem, 2019, pp.1-72.

[18] Fruzsina, Fülöp, Maria, B. Maros: A comparative study on the effect of surface preparation on the friction behaviour of the DLC coating on a cold work tool steel substrate, In: International Workshop on Woman in Ceramic Science (WoCeram 2019): Book of Abstracts, 2019, p.13. 